\title{
Comparison of Fatty Acid Composition between Female and Male Japanese Quail Meats
}

\author{
Umit Gecgel, ${ }^{1}$ Ismail Yilmaz, ${ }^{1}$ Eser Kemal Gurcan, ${ }^{2}$ \\ Salih Karasu, ${ }^{3}$ and Gizem Cagla Dulger ${ }^{4}$ \\ ${ }^{1}$ Food Engineering Department, Faculty of Agriculture, Namik Kemal University, 59030 Tekirdag, Turkey \\ ${ }^{2}$ Animal Science Department, Faculty of Agriculture, Namik Kemal University, 59030 Tekirdag, Turkey \\ ${ }^{3}$ Food Engineering Department, Yildiz Technical University, Istanbul, Turkey \\ ${ }^{4}$ Arda Vocational School, Trakya University, 22030 Edirne, Turkey \\ Correspondence should be addressed to Umit Gecgel; ugecgel@nku.edu.tr
}

Received 20 January 2015; Accepted 25 April 2015

Academic Editor: Giuseppe Gattuso

Copyright (C) 2015 Umit Gecgel et al. This is an open access article distributed under the Creative Commons Attribution License, which permits unrestricted use, distribution, and reproduction in any medium, provided the original work is properly cited.

\begin{abstract}
The objective of the present study was to compare the proximate analysis, fatty acids composition, omega fatty acids, trans fatty acids (TFAs), and ratio of the total poly unsaturated fatty acid ( PPUA) and total saturated fatty acid ( $\Sigma$ SFA) of female and male quail meats. Significant differences were not observed between $\mathrm{pH}$, crude fat, moisture, and ash content of female and male quail meats $(p>0.05)$. The male quail meat had higher fat and ash contents and lower moisture content than those of the female quail meat. The pHs of male and female quail meat were found to be 6.22 and 6.21 , respectively. The results of the fatty acid composition analysis showed that C18:1 (42.14-41.23\%), C16:0 (24.31-25.76\%), C18:2 (13.82-13.42\%), and C18:0 (7.49-7.32\%) were found as the major fatty acids in the female and male quail meats. Total TFAs, $\Sigma$ SFA, monounsaturated fatty acids ( $\Sigma$ MUFA), and $\Sigma$ PUFA content of the female and male quail meats were found to be $2.79-2.82 \%, 33.22-34.65 \%, 49.70-48.72 \%$, and $14.29-13.81 \%$, respectively.
\end{abstract}

\section{Introduction}

Japanese quail (Coturnix coturnix japonica) is used as a model animal and is one of the smallest birds used for its egg and meat production $[1,2]$. Usually, quails are smallto-medium sized birds, belonging to the same biological family of chicken and pheasants (Phasianidae), given the overall similarity in physical characteristics and behavior [3]. However, quail provides more advantages than the chicken such as its resistance to many poultry diseases that afflict chickens, its greater capacity to benefit from food, high reproduction proportions, and also low feed intake [4]. With having the carcass containing $76 \%$ of meat, $14 \%$ of skin, and $10 \%$ of bone, quail has the highest amount of meat and the least bone ratio among the other fowls [5]. Quails are mostly used for human consumption. In spite of their distribution in the wild spreads over large areas of Asia, Europe, and Africa, they were first domesticated in Japan [6] and then in the beginning of the 20th century commercial production started in there. After that, its commercial production became widespread in China and Europe [3]. Japanese quail is used for egg and meat production chiefly in Middle East and America but also in the Asia and Europe [7]. In Europe, the highest consumption of quail meat is in France, Italy, and Spain, respectively [8]. In Turkey, quail is generally known to be a game bird. Since quail breeding is limited to small family farms, sale of quail meat is specifically found in hotels, restaurants, and rarely in supermarkets. The amount of quail meat produced in Turkey is not clearly known due to both shortness of its market and low control over its production $[9,10]$.

Quail meat has been known for centuries despite of the biblical quotations of their use as a meat source [3]. Quail meat is recommended for the low fat diet because it contains low amount of fat and cholesterol especially thanks to its thin skin and low fat accumulation between its tissues [11]. Lately, quail meat has gained much popularity among consumers [12]. It is an ideal food for all ages due to its high meat yield, 
less shrinkage during cooking, being more effortless to cook, and being more easy to serve [13]. Similar to white meat, quail meat has some advantages compared to red meat in terms of including low fat content and low cholesterol [14]. Quail is one of the leanest types of poultry [3] and all the types of quails are good sources of some vitamins such as niacin, thiamin, vitamin B6, riboflavin, and pantothenic acid [15]. The benefits of quail meat are known as high protein, essential fatty acids, and minerals such as sodium, potassium, and iron. Owing to high metabolic activity in this animal, the amount of glycogen stored in muscles increases and results in high quality meat [16].

Fatty acids play significant metabolic, structural, and functional roles in physiology [17]. It is well known that there are different constitutions in point of fatty acids structure; fatty acids include carbon, oxygen, and hydrogen and are categorized as saturated fatty acids (SFAs), monounsaturated fatty acids (MUFAs), or polyunsaturated fatty acids (PUFAs) [18]. SFAs and trans fatty acids (TFAs) give rise to negative effects on human health such as cardiovascular disease, endothelial dysfunction, coronary heart disease, the resistance to insulin, increased levels of blood lipids, inflammation, and the increase in LDL/HDL ratio, [19-22] while PUFAs have a positive effect on human health [23]. Thus, the importance of the PUFAs such as omega-3 (n-3) and omega-6 (n-6) acids in the diet has importantly become more important [24]. The content and particularly the ratio of fatty acids of the n-3 and n- 6 groups are also especially significant [25]. Moreover, quail meat includes these important essential fatty acids, namely, linoleic acid (C18:2, n-6) and $\alpha$-linolenic acid (C18:3, n-3) [26]. The aim of the present study was to investigate the fatty acid composition, omega fatty acids and trans fatty acid contents of female and male Japanese quail meats.

\section{Materials and Methods}

2.1. Animal Material. The experiment was conducted at the Poultry Research Unit of Namik Kemal University, Tekirdag, in Turkey. The quail chicks were managed from birth up to 56 days of age in the present study. All animals were raised in quail battery brooders until 3 weeks of age and thereafter quails were located in the growing battery cages. The chicks were fed on starter and growing feeds of $28 \%$ crude protein and $3050 \mathrm{kcal} \mathrm{kg}^{-1}$ of metabolic energy and $20 \%$ crude protein and $2900 \mathrm{kcal} \mathrm{kg}^{-1}$ of metabolic energy, respectively. Feed and water were given ad libitum to all animals in the cages. Lighting was applied as the ratio of $23: 1$ and $16: 8 \mathrm{~h}$ (light cycle: dark cyle in a day) for 1st week and after first week, respectively.

A total of 60 quails of which 35 female and 25 male animals were used in this trial. At the end of the experiment, 10 female and 10 male birds were randomly chose and then slaughtered. Each of the quail samples was individually labelled and transported at $4^{\circ} \mathrm{C}$ in cooling box to the Namik Kemal University meat laboratory for fat extraction, fatty acids, and omega and trans fatty acids analyses. The quail meat samples were stored at $-18^{\circ} \mathrm{C}$ before the analyses.
2.2. Proximate Composition. Moisture, crude fat, and ash content of quail meat were determined according to methods described by AOAC [27]. The pHs of the samples were determined using a $\mathrm{pH}$ meter according to the method described by Du and Ahn [28].

2.3. Fatty Acid Methyl Esters (FAMEs) Analyses. For fat content determination lipids were extracted from $10 \mathrm{~g}$ breast by the method described by Folch et al. (1959) [29] and AOAC (1990) [27]. $5 \mathrm{~mL}$ chloroform/methanol $(2: 1, \mathrm{v} / \mathrm{v})$ solution was added to sample and shook thoroughly by vortex for $3 \mathrm{~min} .1 \mathrm{~mL}$ of $0.9 \% \mathrm{NaCl}$ was added to mix and shake again. The chloroform phase containing lipids were collected.

Lipid extracts were converted to fatty acid methyl esters (FAMEs) as described by AOAC (1990) [30]. FAME was prepared after alkaline hydrolysis following procedures. Briefly, lipid extract was mixed with $0.5 \mathrm{~N} 2 \mathrm{~mL}$ methanolic $\mathrm{NaOH}$ and held at $100^{\circ} \mathrm{C}$ for $10 \mathrm{~min}$. This solution was cooled to room temperature and mixed with $2 \mathrm{~mL}$ of methanolic $\mathrm{BF}_{3}(14 \%)$. Then after, solution obtained by adding $\mathrm{BF}_{3}$ was incubated at $100^{\circ} \mathrm{C}$ for $2 \mathrm{~min}$ and cooled dawn to again room temperature. $1 \mathrm{~mL}$-heptane was added to final solution and thoroughly mixed by vortex for $3 \mathrm{~min}$ and reheated to $100^{\circ} \mathrm{C}$ for $1 \mathrm{~min}$. Final solution was cooled down to room temperature and centrifuged at $300 \mathrm{rpm}$ for $5 \mathrm{~min}$. Upper layer (heptane phase) was transferred to glass tube for the GC analysis. The final concentration of the FAME was approximately $7 \mathrm{mg} / \mathrm{mL}$ in heptane.

2.4. GC Condition. Gas chromatography (GC) analysis was carried out using Hewlett-Packard 6890 model gas chromatograph equipped with a flame ionization detector (FID) and a split injector (Chrompack, Middleburg, Netherlands). A fused-silica capillary column was used $(100 \mathrm{~m} \times 0.25 \mathrm{~mm}$ i.d. and $0.2 \mu \mathrm{m}$ film thickness, Chrompack). The oven temperature programming consisted of an initial temperature of $120^{\circ} \mathrm{C}$ held for $1 \mathrm{~min}$. Then the temperature was raised to $230^{\circ} \mathrm{C}$ at rate of $3^{\circ} \mathrm{C} / \mathrm{min}$ and was held constant at $230^{\circ} \mathrm{C}$ for $20 \mathrm{~min}$. The injector and detector were kept at $250^{\circ} \mathrm{C}$ with gas flows of $40 \mathrm{~mL} / \mathrm{min}$ for hydrogen and $450 \mathrm{~mL} / \mathrm{min}$ for air. Helium is used as a carrier gas at the flow rate of $1 \mathrm{~mL} / \mathrm{min}$. The GC was equipped with a split injector; a single injection volume of $1 \mu \mathrm{L}$ was made per sample duplicate, using a split ratio of $1: 100$. The peaks were identified by comparing the retention times and area percentages with those of authentic standards of FAMEs obtained from Nu-Chek-Prep Inc. and on the basis of literature data [31]. Three replicate GC analyses were carried out and the results were denoted in GC area \% as a mean value.

2.5. Statistical Analysis. The data obtained from ten replications were analyzed by ANOVA which is completely randomized design. Differences among the means were compared using Duncan's multiple range tests [32]. The statistical analyses were done with the SPSS statistical package program [33]. 


\section{Results and Discussion}

The proximate compositions of quail meat from female and male quail meat are presented in Table 1 . The meat of male quail had higher fat and ash contents and lower moisture content than female quail meat. Moisture and ash contents of quail meats in this study were lower than that of the results of previously reported publications $[3,34]$. The $\mathrm{pH}$ of the male quail meat was ranged from 5.87 to 6.53 and slightly higher than that of the female quail meat (Table 1) and no significant differences were detected $(p>0.05)$. The $\mathrm{pH}$ of meat depends on glycogen content in muscle [25]. Richardson and Mead [35] reported that the $\mathrm{pH}$ of a normal muscle of poultry is approximately 7.2 , and after that death the muscle acidifies to values of 6.0 or less owing to the accumulation of lactic acid.

The SFAs compositions of female and male quail meats are shown in Table 2. Palmitic acid (C16:0) was the major fatty acid, followed by stearic acid (C18:0) in female and male quail meats. The sum of these fatty acids was found to be $95.72 \%$ of total SFAs content of female quail meat and $95.46 \%$ of total SFAs content in male quail meat. The percentage of C16:0 in male quail meats was significantly higher than that of the female quail meats $(p<0.05)$. Similarly, SFAs had significantly lower levels of female quail meats $(p<$ 0.05 ), when compared to the male quail meats (Table 1 ). Genchev et al. [25] reported that SFA contents were found as $34.13 \%$ and $33.72 \%$ for quail breast meat and quail leg meat, respectively. Boni et al. [3] reported that young and spent quail meats contained $25.84 \%$ and $29.07 \%$ SFAs, respectively. SFAs should be taken into account for reduction of the risk of hypercholesterolemia. Most significant ones can be written as lauric (C12:0), myristic (C14:0), and C16:0 acid [3]. Romero et al. [36] reported that SFAs should be taken into consideration to raise plasma cholesterol, except for C18:0 which decreased total and LDL cholesterol. The main fatty acids responsible for the cholesterol elevating effect are C14:0 and C16:0 acids [37]. Moreover, C18:0 is an unusual SFA since it does not elevate blood cholesterol levels to the same extent as other fatty acids. Possible explanations for this disparity may include chain length, inefficient absorption, metabolism kinetics, and hepatic desaturation of stearic into oleic acid [38].

MUFAs were found to be major component as shown in Table 3. Among the MUFAs, the highest content was the oleic acid (C18:1, n-9). Our results were in agreement with another previously published study that revealed that C18:1 was the major fatty acid in Japanese quail meats $[3,25$, 34]. According to Table 3, female quail meats contain more C18:1 than male quail meats. The MUFAs such as oleic acid have great attention due to their beneficial effects on human health and oxidative stability of oils. Oleic acid is a fatty acid that occurs naturally in various animal and vegetable fats and is categorized in MUFA omega-9 fatty acid [39]. In addition, C18:1 is one of the dominant fatty acids in foods of animal origin which are extensively consumed in Western diets, such as poultry and pork [40]. On the other hand, C18:1 has a beneficial effect of decreasing plasma cholesterol and it has been estimated to lessen coronary heart disease risk by $20-40 \%$ principally by means of reduction of LDL cholesterol [41]. Japanese quail meat should be taken into consideration due to high oleic acid contents and prevention of heart diseases. The contents of palmitoleic acid (C16:1) in female quail meats were found to be $6.99 \%$ and significantly $(p<0.05)$ higher than that of the mail quail meats. Minor MUFAs in the quail meats were C15:1, C20:1, and C24:1, and their contents were less than $1 \%$ in the meats and were not significantly differed $(p>0.05)$.

As can be seen from Table 3, there was no significant difference between PUFAs of female and male quail meats. Linoleic acid (C18:2, n-6) was the major PUFA for female and male quail meats and its contents were found to be 13.82 and 13.42, respectively. The content of linolenic acid (C18:3, $\mathrm{n}-3)$ was $0.47 \%$ in female quail meats and 0.39 in male quail meats $(p>0.05)$. The ratio between $n-6$ and n-3 PUFA was found 31.17 in female quail meat and 37.87 in male quail meat $(p<0.05)$. The $n-6$ and $n-3$ fatty acids ratio may have varied depending on quail diet. Oils from plants (corn, soybean, and sunflower) are generally contained in poultry diets, and these oils are rich in n-6 PUFA [24]. On the other hand, vegetable sources, such as flax oil and rapeseed oil, may clearly increase the n-3 fatty acid in the form of linolenic acid [42].

Unsaturated fatty acids (UFAs) constituted are 63.95\% and $62.54 \%$ of the total fatty acids of female and male quail meats, respectively (Table 3 ). Our results for the UFAs are in accordance with Genchev et al. [25] and reported that UFAs contents in breast and legs quail meat were 65.68 and $66.04 \%$, respectively. However, Boni et al. [3] reported that UFAs contents in young and spent quail meats are more than our results. The differences between fatty acids composition might have resulted from diet. In this regard, there are many studies reported by some researchers $[4,16,18,24,43]$. On the other hand, fat content and composition of diets affect human health such as risk of cancer, diabetes, and cardiovascular diseases [17]. For these and some other diseases, UFAs are widely taken into account to have a more beneficial biological effect. But, there is still debate over whether MUFAs or PUFAs have the most beneficial effect [36].

C18.1 trans fatty acid (C18:1tr) of female and male quail meats $(2.08 \%, 2.10 \%)$ was the highest trans fatty acid, followed by C16:1tr $(0.31,0.34), \mathrm{C} 18: 2 \operatorname{tr}(0.19,0.15), \mathrm{C} 17: 1 \operatorname{tr}(0.14,0.14)$, and C18:3tr $(0.07,0.09)$, respectively (Table 3$)$. The amount of TFAs in female and male quail meat is generally low and this may be explained by the lack of availability of TFAs in their feed. TFAs can be present in poultry at minor levels due to the animals consuming feed that includes trans-fats [44]. Actually, the body of fat ruminants may contain TFAs owing to bacterial biohydrogenation [45]. As a result of this, fats from animal sources such as dairy and meat products generally contain between $2 \%$ and $4.5 \%$ of their total fat as TFAs [44].

When SFAs and PUFAs are consumed together, their ratio (the $\mathrm{P}: \mathrm{S}$ ) is an important measure of the relative risk factor of the cholesterol content in a foodstuff [46]. Female and male quail meats consisted $\mathrm{P}: \mathrm{S}$ ratio of 0.43 and 0.40 , respectively (Table 3). Genchev et al. [25] reported that P:S ratio in quail meat was higher than our results. The differences in $\mathrm{P}: \mathrm{S}$ ratio of the quail meats might have resulted from diet. World Health Organization (WHO) has recommended a $\mathrm{P}: \mathrm{S}$ ratio above 0.4 [47]. According to the results of our research, quail 


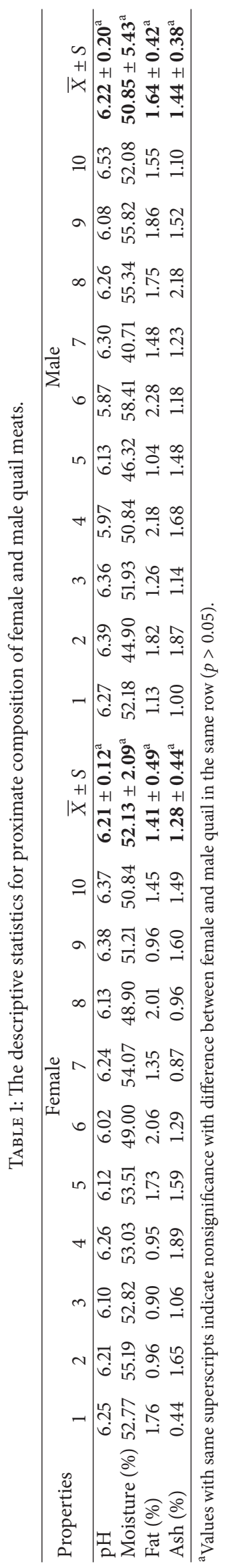




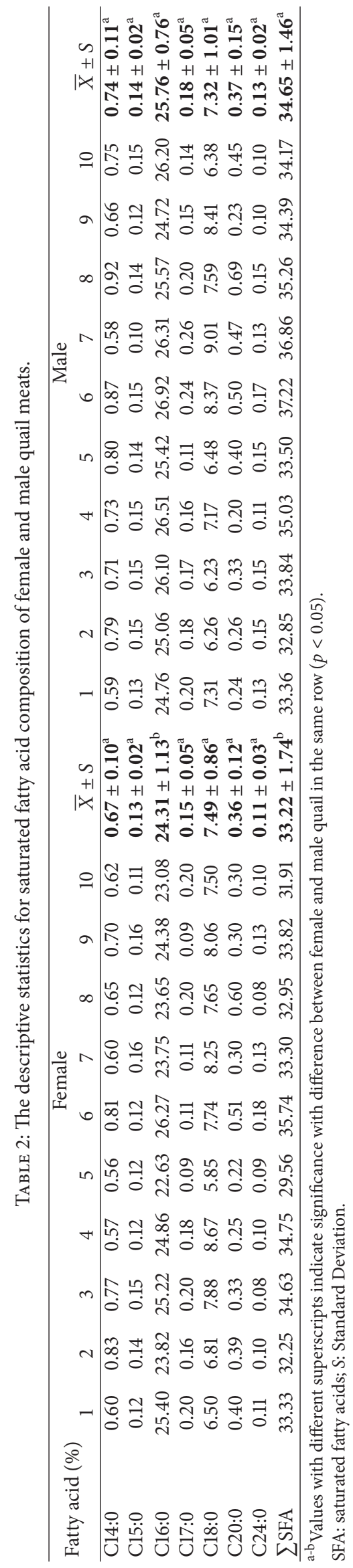




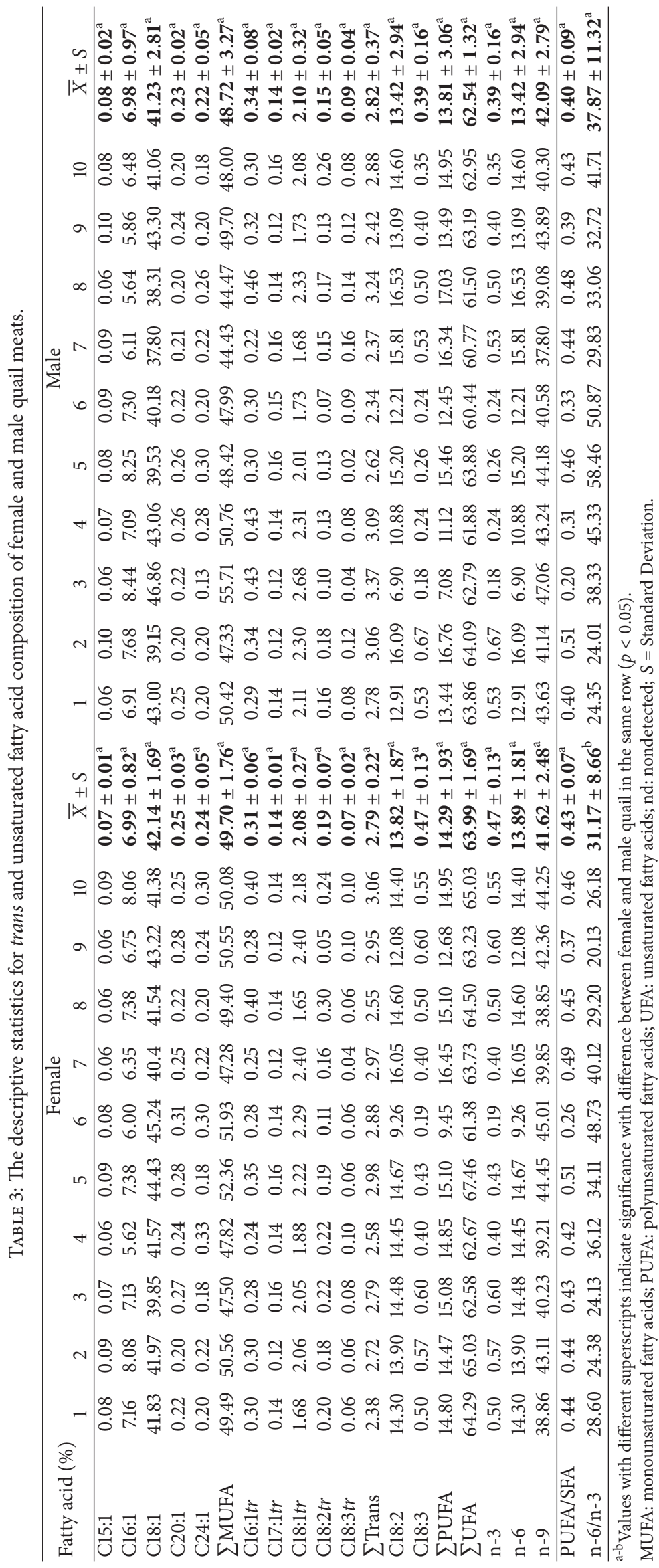


meat may have a low risk factor in terms of cholesterol content compared to other animal meat resources, particularly red meats of mammalian family.

\section{Conclusions}

In conclusion, the fatty acid composition of female and male quail meat is composed by four major fatty acids. C18:1 was the highest fatty acid followed by C16:0, C18:2, and C18:0. Female quail meat had higher C18:1, C18:2, and C18:0 content while male quail meat had higher $\mathrm{C} 16: 0$ content. Japanese quail meat may be taken into consideration in diet for prevention of heart diseases because of high C18:1 content. The ratio between PUFAs and SFAs was 0.43 in female quail meat and 0.40 in male quail meat. Both ratios are in accordance with the WHO recommendations.

\section{Conflict of Interests}

The authors declare that there is no conflict of interests regarding the publication of this paper.

\section{References}

[1] M. Shokoohmand, Quail Production, Noorbakhsh Publication Company, Tehran, Iran, 2008.

[2] D. Narinc, T. Aksoy, E. Karaman, A. Aygun, M. Z. Firat, and M. K. Uslu, "Japanese quail meat quality: characteristics, heritabilities, and genetic correlations with some slaughter traits," Poultry Science, vol. 92, no. 7, pp. 1735-1744, 2013.

[3] I. Boni, H. Nurul, and I. Noryati, "Comparison of meat quality characteristics between young and spent quails," International Food Research Journal, vol. 17, no. 3, pp. 661-667, 2010.

[4] T. C. Santos, A. E. Murakami, J. C. Fanhani, and C. A. L. Oliveira, "Production and reproduction of egg- and meat-type quails reared in different group sizes," Brazilian Journal of Poultry Science, vol. 13, no. 1, pp. 9-14, 2011.

[5] L. P. Posati, Composition of Foods: Poultry Products-Raw, Processed, Prepared, Agriculture Handbook, vol. 330, USDA Human Nutrition Information Service, Washington, DC, USA, 1979.

[6] M. Mizutani, The Japanese Quail, Laboratory Animal Research Station, Nippon Institute for Biological Science, Yamanashi, Japan, 2009, http://www.angrin.tlri.gov.tw/apec2003/Chapter5JPQuail.pdf.

[7] F. Minvielle, "The future of Japanese quail for research and production," World's Poultry Science Journal, vol. 60, no. 4, pp. 500-507, 2004.

[8] A. S. Tserveni-Gousi and A. L. Yannakopoulos, "Carcase characteristics of Japanese quail at 42 days of age," British Poultry Science, vol. 27, no. 1, pp. 123-127, 1986.

[9] M. Sarica, O. Camci, and E. Selcuk, Bıldırcın, Sülün, Keklik, Etçi Güvercin, Beçtavuğu ve Devekuşu Yetiştiriciliği, Ondokuz Mayıs Üniversitesi Ziraat Fakültesi Baskı Ünitesi, Samsun, Turkey, 2013, (Turkish).

[10] Anonymous, 2011 (Turkish), http://www.kanatliforum.com/ index.php?topic $=6.0$.

[11] O. F. Alarslan, Modern bıldırcın üretimi ve temel besleme ilkeleri, Ankara Üniversitesi, Ziraat Fakültesi, Zootekni Bölümü, 1st edition, 2006, (Turkish).
[12] B. Ikhlas, N. Huda, and I. Noryati, "Chemical composition and physicochemical properties of meatballs prepared from mechanically deboned quail meat using various types of flour," International Journal of Poultry Science, vol. 10, no. 1, pp. 30-37, 2011.

[13] G. J. Mountney, Poultry Products Technology, The AVI Publishing Company, Westport, Conn, USA, 2nd edition, 1981.

[14] S. Jaturasitha, P. Thirawong, V. Leangwunta, and M. Kreuzer, "Reducing toughness of beef from Bos indicus draught steers by injection of calcium chloride: effect of concentration and time postmortem," Meat Science, vol. 68, no. 1, pp. 61-69, 2004.

[15] D. Hamm and C. Y. W. Ang, "Nutrient composition of quail meat from three sources," Journal of Food Science, vol. 47, no. 5, pp. 1613-1614, 1982.

[16] B. Aminzade, B. Karami, and E. Lotfi, "Meat quality characteristics in Japanese quails fed with Menthapiperita plant," Animal Biology \& Animal Husbandry, vol. 4, pp. 20-23, 2012.

[17] L. Mennicken, S. Ponsuksili, E. Tholen et al., "Divergent selection for $\omega 3: \omega 6$ polyunsaturated fatty acid ratio in quail eggs," Archiv fur Tierzucht, vol. 48, no. 5, pp. 527-534, 2005.

[18] H. J. Al-Daraji, H. A. Al-Mashadani, W. K. Al-Hayani, H. A. Mirza, and A. S. Al-Hassani, "Effect of dietary supplementation with different oils on productive and reproductive performance of quail," International Journal of Poultry Science, vol. 9, no. 5, pp. 429-435, 2010.

[19] S. Asgary, B. Nazari, N. Sarrafzadegan, S. Saberi, L. Azadbakht, and A. Esmaillzadeh, "Fatty acid composition of commercially available Iranian edible oils," Journal of Research in Medical Sciences, vol. 14, no. 4, pp. 211-215, 2009.

[20] C. Benincá, E. F. Zanoelo, L. F. de Lima Luz Jr., and C. B. Spricigo, "Trans fatty acids in margarines marketed in Brazil: content, labeling regulations and consumer information," European Journal of Lipid Science and Technology, vol. 111, no. 5, pp. 451-458, 2009.

[21] E. K. Richter, K. A. Shawish, M. R. L. Scheeder, and P. C. Colombani, "Trans fatty acid content of selected Swiss foods: the TransSwissPilot study," Journal of Food Composition and Analysis, vol. 22, no. 5, pp. 479-484, 2009.

[22] J. Mayneris-Perxachs, I. Bondia-Pons, C. Moltó-Puigmartí, M. Pairó, A. I. Castellote, and M. C. López-Sabater, "Diet and plasma evaluation of the main isomers of conjugated linoleic acid and trans-fatty acids in a population sample from Mediterranean North-east Spain," Food Chemistry, vol. 123, no. 2, pp. 296-305, 2010.

[23] D. Bhatnagar and P. N. Durrington, "Omega-3 fatty acids: their role in the prevention and treatment of atherosclerosis related risk factors and complications," International Journal of Clinical Practice, vol. 57, no. 4, pp. 305-314, 2003.

[24] O. N. Ertas, T. Güler, M. Çiftçi, B. Dalkiliç, and O. Yilmaz, "The effect of a dietary supplement coriander seeds on the fatty acid composition of breast muscle in Japanese quail," Revue de Medecine Veterinaire, vol. 156, no. 10, pp. 514-518, 2005.

[25] A. Genchev, G. Mihaylova, S. Ribarski, A. Pavlov, and M. Kabakchiev, "Meat quality and composition in Japanese Quails," Trakia Journal of Sciences, vol. 6, pp. 72-82, 2008.

[26] M. Enser, K. Hallett, B. Hewitt, G. A. J. Fursey, and J. D. Wood, "Fatty acid content and composition of English beef, lamb and pork at retail," Meat Science, vol. 42, no. 4, pp. 443-456, 1996.

[27] AOAC, Association of Analytical Chemists. Offical Methods of Analysis, AOAC International, Arlington, Va, USA, 18th edition, 2005. 
[28] M. Du and D. U. Ahn, "Effect of dietary conjugated linoleic acid on the growth rate of live birds and on the abdominal fat content and quality of broiler meat," Poultry Science, vol. 81, no. 3, pp. 428-433, 2002.

[29] J. M. Folch, M. Lees, and G. H. S. Stanley, "A simple method for the isolation and purification of total lipides from animal tissues," The Journal of Biological Chemistry, vol. 226, no. 1, pp. 497-509, 1957.

[30] AOAC, Official Methods for the Analysis, Association of Official Analytical Chemists, Arlington, Va, USA, 15th edition, 1990.

[31] R. Pawlłowicz and B. Drozdowski, "Separation of geometrical isomers of unsaturated fatty acids by gas-liquid chromatography on CP-Sil 88 and DB-23 columns," Chemia Analityczna, vol. 43, no. 6, pp. 961-967, 1998.

[32] I. Soysal, Biometrinin Temel Prensipleri. (Principles of Biometric Analysis), publish no. 95, Trakya University, Faculty of Agricultural, Tekirdağ, Turkey, 1992.

[33] SPSS, SPSS Advanced Models, 11.0 SPSS, Chicago, Ill, USA, 2001.

[34] R. A. El-Dengawy and A. M. Nassar, "Investigation on the nutritive value and microbiological quality of wild quail carcasses," Nahrung/Food, vol. 45, no. 1, pp. 50-54, 2001.

[35] R. I. Richardson and G. C. Mead, Poultry Meat Science, vol. 25 of Poultry Science Symposium Series, CABI Publishing, 1999.

[36] M. C. Romero, A. M. Romero, M. M. Doval, and M. A. Judis, "Nutritional value and fatty acid composition of some traditional Argentinean meat sausages," Food Science and Technology, vol. 33, no. 1, pp. 161-166, 2013.

[37] L. M. Valsta, H. Tapanainen, and S. Männistö, "Meat fats in nutrition," Meat Science, vol. 70, no. 3, pp. 525-530, 2005.

[38] F. M. Steinberg, M. M. Bearden, and C. L. Keen, "Cocoa and chocolate flavonoids: implications for cardiovascular health," Journal of the American Dietetic Association, vol. 103, no. 2, pp. 215-223, 2003.

[39] S. Khodadoust, A. Mohammadzadeh, J. Mohammadi, C. Irajie, and M. Ramezani, "Identification and determination of the fatty acid composition of Quercus brantii growing in southwestern Iran by GC-MS," Natural Product Research, vol. 28, no. 8, pp. 573-576, 2014.

[40] J. Linseisen, E. Kesse, N. Slimani et al., "Meat consumption in the European Prospective Investigation into cancer and nutrition (EPIC) cohorts: results from 24-hour dietary recalls," Public Health Nutrition, vol. 5, no. 6, pp. 1243-1258, 2002.

[41] P. M. Kris-Etherton, "Monounsaturated fatty acids and risk of cardiovascular disease," Circulation, vol. 100, no. 11, pp. 12531258, 1999.

[42] H. J. Al-Daraji, H. A. Al-Mashadani, H. A. Mirza, M. K. Al-Hayani, and A. S. Al-Hassani, "Effect of feeds containing different fats on certain carcass parameters of Japanese Quail," ARPN Journal of Agricultural and Biological Science, vol. 6, pp. 6-11, 2011.

[43] T. Ebeid, A. Fayoud, S. Abou El-Soud, Y. Eid, and M. ElHabbak, "Te effect of omega-3 enriched meat production on lipid peroxidation, antioxidative status, immune response and tibia bone characteristics in Japanese quail," Czech Journal of Animal Science, vol. 56, no. 7, pp. 314-324, 2011.

[44] I. Yilmaz and U. Geçgel, "Effects of gamma irradiation on trans fatty acid composition in ground beef," Food Control, vol. 18, no. 6, pp. 635-638, 2007.

[45] E. A. Decker and Y. Park, "Healthier meat products as functional foods," Meat Science, vol. 86, no. 1, pp. 49-55, 2010.
[46] L. C. Hoffman, L. L. Laubscher, and K. Leisegang, "Nutritional value of cooked offal derived from free-range rams reared in South Africa," Meat Science, vol. 93, no. 3, pp. 696-702, 2013.

[47] World Health Organization (WHO), WHO Technical Report Series, no: 916 (TRS 916), 2014, http://www.who.int. 

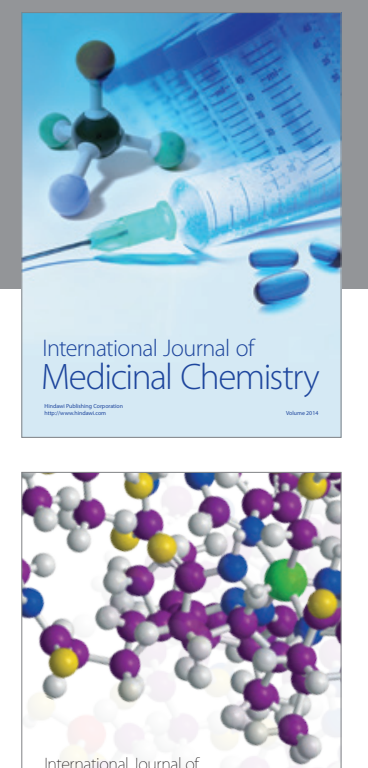

\section{Carbohydrate} Chemistry

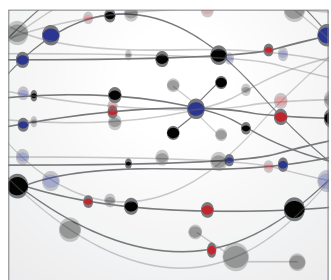

The Scientific World Journal
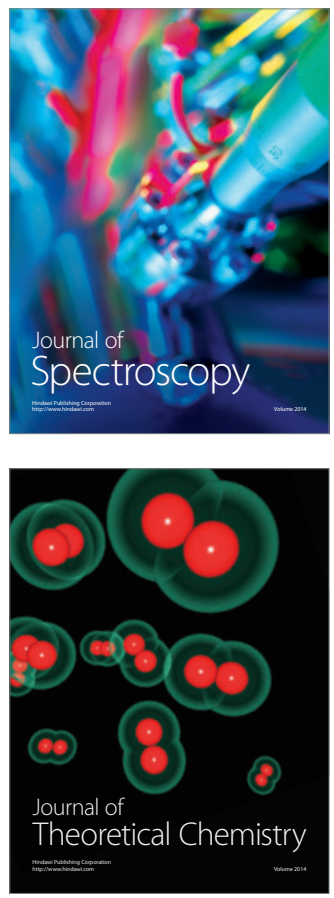
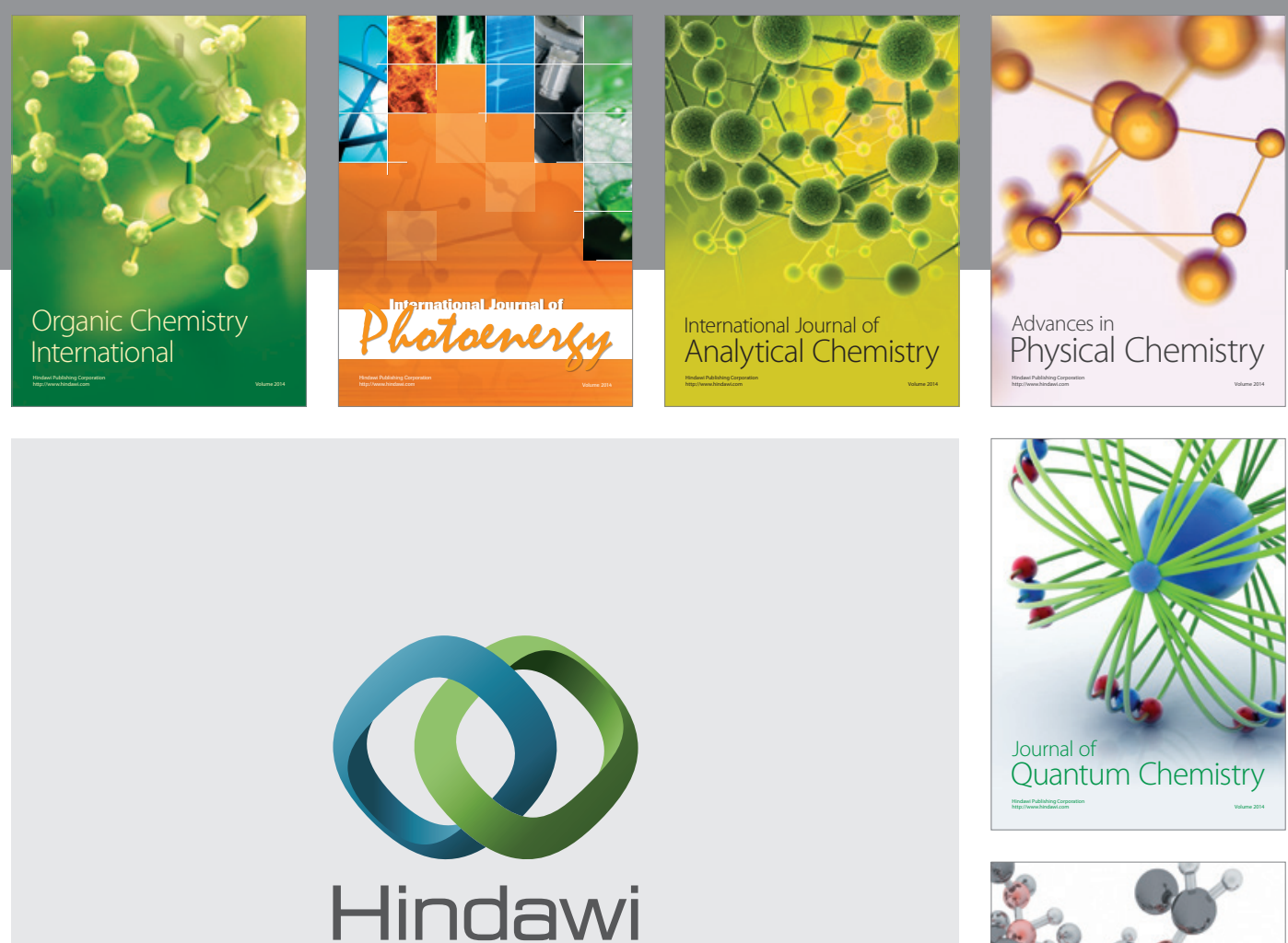

Submit your manuscripts at

http://www.hindawi.com

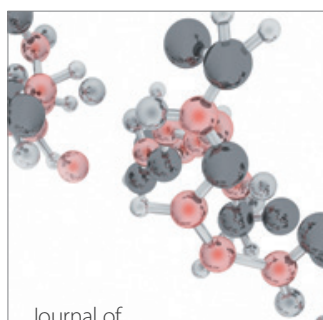

Analytical Methods

in Chemistry

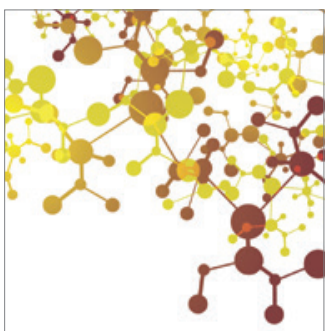

Journal of

Applied Chemistry

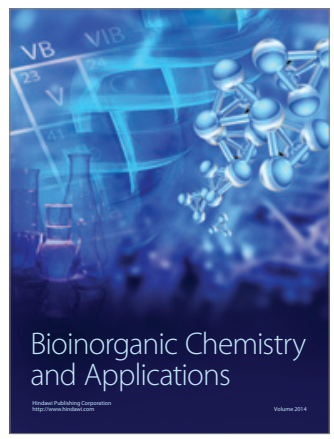

Inorganic Chemistry
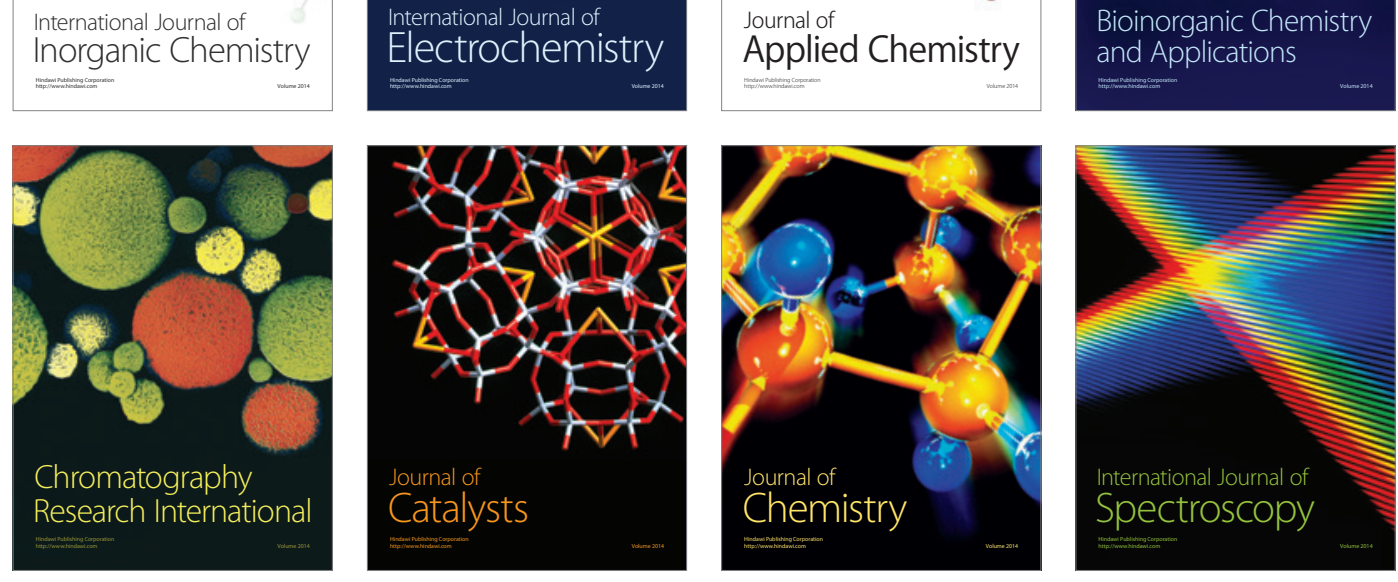